\title{
Antioxidative and Antibacterial Ethanol Extract from a Neglected Indigenous Myco-food Suppresses Hep3B Proliferation by Regulating ROS-driven Intrinsic Mitochondrial Pathway
}

\author{
Somanjana Khatua ${ }^{1}$ (I) , Krishnendu Acharya ${ }^{1, *}$ (D) \\ 1 Molecular and Applied Mycology and Plant Pathology Laboratory, Centre of Advanced Study, Department of Botany, \\ University of Calcutta, 35, Ballygunge Circular Road, Kolkata - 700019, West Bengal, India \\ * Correspondence: krish_paper@yahoo.com;
}

Received: 13.11.2020; Revised: 4.12.2020; Accepted: 6.12.2020; Published: 9.12.2020

\begin{abstract}
Food has always been an important way in many medical systems to treat illness. Despite the credence, many ethnic nutrients meet sturdy resistance due to a lack of evidence-based knowledge. Russula senecis is one of such forgotten myco-resource that has historically been cherished as healthpromoting food; yet remains abandoned in the city market. To save the indigenous culture and popularize locally available functional food, we planned to explore the taxon's health benefits. The ethanolic fraction was enriched in phenolics (pyrogallol> cinnamic acid) followed by a flavonoid, ascorbic acid, $\beta$-carotene, and lycopene. Further investigation demonstrated that the preparation was capable enough to scavenge free radicals (superoxide, DPPH, ABTS), prevent $\beta$-carotene bleaching, donate an electron, and chelate $\mathrm{Fe}^{2+}$ with $\mathrm{EC}_{50}$ of $122-1151 \mu \mathrm{g} / \mathrm{ml}$. Besides, the significant antibiotic property was also recorded against tested pathogenic microbes, as evidenced by low MIC scores (48.5$529 \mu \mathrm{g} / \mathrm{ml}$ ). Moreover, the extract selectively rendered Hep3B cell proliferation as the treatment provoked a rapid increase in intracellular ROS resulting DNA breakage, cell cycle arrest, $\Delta \Psi \mathrm{m}$ decrease, imbalance in Bax/Bcl-2 ratio, and activation of caspase-9 signifying induction of intrinsic mitochondrial pathway. Thus the study recommends the use of $R$. senecis in medicinal, pharmaceutical, and food industries for the betterment of humankind.
\end{abstract}

Keywords: free radicals; hepatcellular carcinoma; HPLC; pathogenic bacteria; phenolics; Russula senecis.

(C) 2020 by the authors. This article is an open-access article distributed under the terms and conditions of the Creative Commons Attribution (CC BY) license (https://creativecommons.org/licenses/by/4.0/).

\section{Introduction}

At present, the entire world is moving towards public health disaster due to dietary risks, life-style difficulties, adverse effects of synthetic drugs, and so forth; thus pursuit for novel remedies takes a compelling urgency. In this context, there is an ever-increasing curiosity to explore medications to treat ailments induced by free radicals, a key component underlying various physiological conditions. These highly reactive constituents with a voracious appetite for electrons attack nearby substances to stabilize themselves, hastening disease progression [1]. At this time, fighters are supplemented to maintain homeostasis, and these defenders are often lumped together as "antioxidants". In the face of their rising demand, scads of artificial compounds have been released in the market; but they have a potential downside. Contrarily 
the ready availability of radical quenchers in food has motivated health experts to recommend antioxidant-rich diets [2].

On the other hand, escalating bacterial resistance against conventional therapies is another pressing issue in the global healthcare system. Joint infections are becoming untreatable. The situation occurs when pathogens adapt to survive in the drugs that would typically inhibit their growth. A recent estimation reflects that fact depicting 700,000 people death per year from contagious diseases, and the figure is projected to increase to 10 million exposures annually by 2050 [3]. Hence new approaches are necessary to fill the antibiotic development pipeline in order to replace the natural pills. This scenario originated the concept to revive the spirit of inquiry for natural antimicrobial products due to their chemical diversity making microbes unable to withstand [4]. Moving forward, cancer remains a leading cause of death across the globe arising from the transformation of normal cells into the tumor through a multistage process. Amongst all types, hepatocellular carcinoma (HCC) is one of the most prevalent and fastest-growing lethal neoplasms accounting for almost 1 million mortalities worldwide per annum. Various risk factors for HCC are well defined, such as hepatitis B and $\mathrm{C}$ virus infection, alcohol consumption, and metabolic syndrome [5]. Despite remarkable progress in cancer research, unfortunately, there is no effective treatment in terms of overall success rate due to limited efficacy or contraindication. Hence over the past few years, demand for more active and less toxic chemoprevention is increasing dramatically in that herbal medicines have come up as a possible strategy against HCC influencing people's aspiration to go back to basics, natural and organic [6].

In that scenario, mushrooms have served as humankind's pharmacy for eons, being appraised for promoting health and longevity, especially in Asia. Therefore, the prevalence of fungi in contemporary Indian curing services should not come as a surprise, especially when one considers their predominance in ancient systems like Ayurveda, Unani, and Siddha [7]. Recent investigation has explored that macromycetes can produce a vast array of compounds, each of which serves a specific role for the fungus itself. However, it is a pity that such glorious stories of many taxa have fainted with time due to confinement of the wisdom in native communities, lack of publicity, and the concept of chemically synthetic drugs [8]. Thus it is important to take a stand in the fast-changing world to save our traditional knowledge before it disappears.

One of such traditionally appraised yet less explored mushrooms is Russula senecis $\mathrm{S}$. Imai, which possesses yellow-colored basidiocarps, an ectomycorrhizal relationship with the host plant-wide distribution. The species was originally described from Japan in 1938, and much later was cited for inhabiting Korea [9], China [10], and India [11]. The specimen was recently recorded during our expedition at West Bengal, India, growing under Castanopsis sp in forests of Darjeeling and Shorea robusta at the lateritic region. To our surprise, interaction with mycophagy elders dwelling particularly in Burdwan, Bankura, and Midnapore districts revealed their belief regarding the macrofungus' health-promoting effects, which was so far hidden from science. For the first time since that survey, we are engaged to analyze the taxon biochemically and pharmacologically, as published earlier [12-14], showing a glimpse of strong therapeutic potency. Despite the fact, the only tip of the iceberg has been uncovered to date in our understanding of the sample. Therefore because of the ethnic importance of $R$. senecis and its biological potential, the objective of this study was to characterize chemical profile and evaluate different bioactive performances like antioxidant, antibacterial and anticancer properties. 


\section{Materials and Methods}

\subsection{Chemicals.}

2,2-diphenyl-1-picrylhydrazyl (DPPH), 2,2'-azino-bis(3-ethylbenzothiazoline-6sulphonic acid) (ABTS), nitroblue tetrazolium (NBT), butylated hydroxyanisole (BHA), FolinCiocalteu (FC), ethylenediaminetetraacetic acid (EDTA), 2,6-dichlorophenolindophenol (DCPIP), $p$-iodonitrotetrazolium chloride (INT), nutrient broth (NB), Dulbecco's Modified Eagle Medium (DMEM), propidium iodide (PI), acridine orange (AO), ethidium bromide (EB), 4',6-diamidino-2-phenylindole (DAPI) and 2',7'-dichlorofluorescin diacetate (DCFDA), were procured from Himedia (Mumbai, India). Fetal bovine serum (FBS) and water-soluble tetrazolium (WST) were obtained from Takara Bio Inc, Japan, and Invitrogen, Carlsbad, CA, USA, respectively. High-performance thin-layer chromatography (HPLC) standards were used from Sigma chemicals Co., St. Louis, MO, USA. 5,5',6,6'-tetrachloro1,1',3,3'tetraethylbenzimidazolcarbocyanine iodide (JC-1) and APO-DIRECT ${ }^{\mathrm{TM}}$ Kit for Terminal deoxynucleotidyl transferase dUTP nick end labeling (TUNEL) assay were used from BD Pharmingen, San Diego, CA, USA.

\subsection{Collection of basidiocarps and authentication.}

Fruit bodies of $R$. senecis were collected under Sal tree in lateritic areas of West Bengal during monsoon season and identified following standard protocol. Subsequently, a representative voucher specimen (Accession no: CUH AM102) was deposited in Calcutta University Herbarium [12].

\subsection{Preparation of ethanol extract.}

Powdered fruit bodies $(10 \mathrm{mg})$ were steeped in $200 \mathrm{ml}$ of absolute ethanol under shaking conditions overnight. The residue was then filtered through Whatman No. 4 and reextracted with $100 \mathrm{ml}$ of ethanol. The combined ethanolic fractions were diminished in volume using a rotary evaporator (Rotavapor R-3, Butchi, Switzerland).

\subsection{Chemical characterization of ethanol extract.}

To quantify total phenolic compounds, the extract solution was mixed with FC reagent and sodium carbonate. After 90 min incubation, the absorbance was monitored at $725 \mathrm{~nm}$. The amount of total flavonoid content was determined using the fraction, aluminum nitrate, and potassium acetate. The reaction mixture was then incubated for around $40 \mathrm{~min}$, and absorbance was noted at $415 \mathrm{~nm}$. Content of carotenoid, including $\beta$-carotene and lycopene was estimated by mixing the preparation with acetone:hexane mixture (4:6). Then, absorbance was measured simultaneously at three different wavelengths: 453, 505, and $663 \mathrm{~nm}$. The presence of ascorbic acid in the formulation was determined following a titration method using DCPIP dye. The fraction was further analyzed by HPLC (Agilent, USA) using Agilent Eclipse Plus C18 column $(100 \mathrm{~mm} \times 4.6 \mathrm{~mm}, 3.5 \mu \mathrm{m})$ to characterize the phenolic compounds. Elution was carried out by using acetonitrile (eluent A) and $0.1 \%$ phosphoric acid solution (eluent B) following an established protocol as described in Khatua et al. [15]. 


\subsection{Evaluation of antioxidative property.}

The scavenging potential of the ethanol extract for superoxide radical $\left(\mathrm{O}_{2}{ }^{\cdot-}\right)$ was analyzed following the method as described by Martinez et al. [16]. The reaction mixture contained phosphate buffer, riboflavin, EDTA, and NBT; afterward, absorbance was measured at $590 \mathrm{~nm}$. To determine DPPH radical scavenging activity, the reaction mixture was prepared in a 96 well plate, which was left to stand for $30 \mathrm{~min}$. It was followed by detecting the final color at $595 \mathrm{~nm}$ using a microplate reader (Bio-Rad iMarkTM Microplate Reader, USA). To estimate ABTS radical quenching effect, freshly prepared $\mathrm{ABTS}^{{ }^{+}}$solution was allowed to react with the preparation at variable dosages in a microtiter plate, and absorbance was noted. The antioxidant activity of the formulation was also evaluated by the $\beta$-carotene linoleate model system. The reaction mixture was briefly prepared by mixing $\beta$-carotene in chloroform, linoleic acid, and Tween 40 where absorbance was read at $490 \mathrm{~nm}$. To assess reducing power, the formulation at different levels was mixed with $\mathrm{K}_{3}\left[\mathrm{Fe}(\mathrm{CN})_{6}\right]$, TCA, and $\mathrm{FeCl}_{3}$; then, absorbance was enumerated at $750 \mathrm{~nm}$. Finally, total antioxidant capacity was determined. For that, the reactant mixture was arranged by adding the extract, $\mathrm{H}_{2} \mathrm{SO}_{4}$, sodium sulfate, and ammonium molybdate. Afterward, absorbance was recorded at $695 \mathrm{~nm}$. By adopting microplate equipment, the binding efficacy of the investigated fraction on metal ions was investigated. The 96 well plates comprised ferrous chloride, a range of concentrations of the preparation, and ferrozine, where absorbance was estimated at $595 \mathrm{~nm}$ [17].

\subsection{Estimation of antibacterial potential.}

Dilutions of $\left(1 \times 10^{5} \mathrm{CFU} / \mathrm{ml}\right)$ Listeria monocytogenes ATCC $^{\circledR} \quad 19111^{\mathrm{TM}}$, Staphylococcus aureus ATCC $^{\circledR} 700699^{\mathrm{TM}}$, Bacillus subtilis ATCC $^{\circledR}$ 6633 ${ }^{\mathrm{TM}}$, Klebsiella pneumoniae ATCC $^{\circledR} 15380^{\mathrm{TM}}$, Salmonella typhimurium ATCC $^{\circledR} 23564^{\mathrm{TM}}$ and Escherichia coli ATCC $^{\circledR} 25922^{\mathrm{TM}}$ were prepared separately. Reactions were performed in 96 well plates consisting of inoculum and different levels of the organic fraction. The plates were incubated at $37^{\circ} \mathrm{C}$ for $24 \mathrm{~h}$, and afterward, INT dye was added, followed by measuring absorbance at 595 $\mathrm{nm}[18]$.

\subsection{Determination of anticancer activity.}

\subsubsection{Cell culture.}

Hep3B and BRL-3A lines, purchased from National Centre for Cell Science, Pune, India, were routinely maintained in DMEM supplemented with $10 \%$ heat-inactivated FBS, $0.25 \%$ amphotericin B $(250 \mu \mathrm{g} / \mathrm{ml})$ and $0.5 \%$ PenStrep $(5,000 \mathrm{IU} / \mathrm{ml}$ penicillin and $5 \mathrm{mg} / \mathrm{ml}$ streptomycin).

\subsubsection{Cytotoxicity, clonogenic cell survival and wound healing assays.}

WST-8 was used to determine cell viability after $24 \mathrm{~h}$ incubation with the investigated drug. Optical density was measured at $450 \mathrm{~nm}$. DMSO was used to dilute the ethanol extract; however, the solvent was added in each well at a concentration, not more than $0.05 \%$ (v/v). For the clonogenic assay, viable cells were seeded into a 6-well plate and treated with fractions at various doses. After $24 \mathrm{~h}$, cells were placed in fresh media, and the plate was returned to the incubator for five to six doubling. To perform wound healing assay, Hep3B cells were cultured in a monolayer up to $90 \%$ confluence in a 12 well plate. Cells were then scraped in a straight 
line to create a scratch. The formulation was added at different levels, and the wound healing was assessed after $24 \mathrm{~h}$ incubation [8].

\subsubsection{Assessment of nuclear and cellular morphology.}

Following $24 \mathrm{~h}$ treatment, hepatocellular cells were fixed and incubated with $1 \mu \mathrm{g} / \mathrm{ml}$ of DAPI solution. Changes in nuclear morphology were observed and photographed with a fluorescent microscope $\left(\right.$ FLoid $^{\circledR}$ Cell Imaging Station, Life Technologies, Carlsbad, CA, USA). For AO/EB dual staining method, cells were exposed to the fraction for $24 \mathrm{~h}$ and suspended with $100 \mu 1$ of AO/EB solution [19]. , The intensity of fluorescent staining was observed, and images were captured.

\subsubsection{Cell cycle analysis.}

After $24 \mathrm{~h}$, treated and untreated cells were suspended in fresh media and centrifuged at 2,000 rpm for $5 \mathrm{~min}$. The pellet was then fixed in $75 \%$ ethanol and kept at $4^{\circ} \mathrm{C}$ overnight. On the next day, cells were re-suspended in PBS containing $0.2 \mathrm{mg} / \mathrm{ml}$ RNase. Further, PI staining solution $(50 \mu \mathrm{g} / \mathrm{ml})$ was added and incubated for $30 \mathrm{~min}$. Finally, the cellular DNA content at different stages of the cell cycle was examined (BD Bioscience, San Jose, CA, USA). Results were analyzed with BD CellQuest Pro software.

\subsubsection{Detection of DNA fragmentation by TUNEL assay.}

After $24 \mathrm{~h}$ treatment, Hep3B cells were fixed, permeabilized with ice-cold ethanol (70\%), and centrifuged. Then DNA labeling solution (containing TdT enzyme and FITCdUTP) was added to the cell pellet. At the end of incubation time, rinse buffer was added. After centrifugation, the cell pellet was suspended in PI/RNase staining buffer as per manufacturer's instruction. Cells were incubated at room temperature for $30 \mathrm{~min}$ and immediately analyzed in a flow cytometer.

2.7.6. Measurement of intracellular ROS and mitochondrial membrane potential (MMP).

Healthy HCC cells were seeded in 6 well plates and incubated with varying concentrations of the formulation for $30 \mathrm{~min}$. DCFDA dye to a final concentration of $5 \mu \mathrm{M}$ was added, and intracellular ROS levels were measured using flow cytometry as mentioned above. The same method was repeated for the estimation of MMP where cells were treated for $24 \mathrm{~h}$. Following incubation with $\mathrm{JC}-1$, the stained cells were detected by flow cytometry; mean fluorescence intensity was calculated and compared with that of untreated cells $[8,19]$.

\subsubsection{Analysis of apoptosis-related gene expression by RT-PCR.}

Reverse transcription was executed with RNA ( $1 \mu \mathrm{g})$ with RT and GO Mastermix as per manufacturer's instruction. To analyze the expression of a specific gene, PCR was performed as described by Khatua et al. [8] using a thermal cycler (Applied Biosystems, Foster City, CA, USA). For each gel, ImageJ software v. 1.46r was applied for numerical assessment of band strength. 


\subsection{Statistical analysis.}

All results presented herein are expressed as mean and standard deviation ( \pm SD) from three experiments $(n=3)$. Differences in mean values between the groups were analyzed by one-way analysis of variance (ANOVA) with posthoc Tukey HSD test using IBM SPSS Statistics for Windows, v. 23.0. (IBM Corp., Armonk, New York, United States). Differences between the control and experimental set were considered significant when $p<0.05\left(^{*}\right)$, very significant when $p<0.01(* *)$, and highly significant when $p<0.001(* * *)$.

\section{Results and Discussion}

\subsection{Chemical characterization of ethanol extract.}

Fungi are an incredibly biosynthetic laboratory, and thus a single extract preparation may contain hundreds of different organic entities [20]. Therefore, the combined action of these bioactive groups can enhance the overall effect in contrast to a single component where the isolation process is time-consuming and requires a large bulk of natural resources [21]. Among these constituents, phenolic compounds, including flavonoids, are extensively studied due to their beneficial role in human health, curing, and disease prevention. Isolation of these therapeutic substances is predominantly reliant on polar extractant media such as ethanol, a safe solvent for human consumption, and identification of chemical classes present in the fraction is essential for pharmacological propensity [22].

3.1.1. Determination of total phenol, flavonoid, carotenoid and ascorbic acid content.

Accordingly, the present study was aimed to isolate an ethyl alcohol extract from $R$. senecis where recovery percentage was enumerated to be $6 \pm 0.1 \%$. The value was superior to that of Gyroporus castaneus [23], Leucopaxillus giganteus, Phellorinia inquinans, and Podaxis pistillaris [24], signifying ability of ethanol to penetrate cells as well as leach out chemicals is partly dependent on an individual specimen. Further investigation on metabolite profiling indicated phenols as the most prevailing compound in the investigated fraction presented as much as $8.52 \pm 0.01 \mu \mathrm{g}$ gallic acid equivalent $/ \mathrm{mg}$ of extract. A notable amount of flavonoids was also detected $(5.08 \pm 0.03 \mu \mathrm{g}$ quercetin equivalent $/ \mathrm{mg}$ of extract), encompassing $59.62 \%$ of the total phenolic cluster. Comparative analysis with previous reports depicted that the amounts were in the higher range than ethanolic preparation of Omphalotus olearius [23], although inferior to hydro-ethanol formulation from R. senecis [12]. Nonetheless, exploration of ascorbic acid content in the studied extract revealed vitamin $C$ 's existence in a moderate degree, i.e., $2.65 \pm 0.38 \mu \mathrm{g} / \mathrm{mg}$ of extract. In contrast, carotenoids including $\beta$-carotene and lycopene were reckoned in the fraction under consideration somewhat in minor extents being presented as $0.06 \pm 0.01$ and $0.05 \pm 0.09 \mu \mathrm{g} / \mathrm{mg}$ of extract, respectively; even though the quantities appeared approximately five times higher than ethanol extract from Russula virescens [25]. Overall, many secondary metabolites were identified in the concerned preparation, which was estimated in the decreasing order of phenol> flavonoid $>$ ascorbic acid $>\beta$-carotene $>$ lycopene.

\subsubsection{HPLC profiling of phenolic compounds.}

Phenolic compounds should be further identified as their element has a specific effect on different physiological systems. In this context, a reliable analytical instrument, HPLC, was employed in the present study to obtain comprehensive results regarding the chemical 
composition of ethanol extract from $R$. senecis. As presented in Figure 1, the chromatogram indicated the existence of at least eleven compounds in the studied fraction, of which two were tentatively recognized. Quantification analysis depicted pyrogallol as the major phenolic substance present in the formulation $(2.07 \pm 0.05 \mu \mathrm{g} / \mathrm{mg}$ of extract) followed by cinnamic acid $(0.15 \pm 0.01 \mu \mathrm{g} / \mathrm{mg}$ of extract). A similar output was also recorded in a hydro-ethanol extract from $R$. senecis [12];. However, in a higher range, the values were summarizing aqueous organic solvent combination might act as a better parameter to extract phenolics. However, the finding partially coincides with Sheikh et al. [26] explaining cinnamic acid manifestation in ethanol extracts from Ganoderma lucidum and Trametes hirsuta.

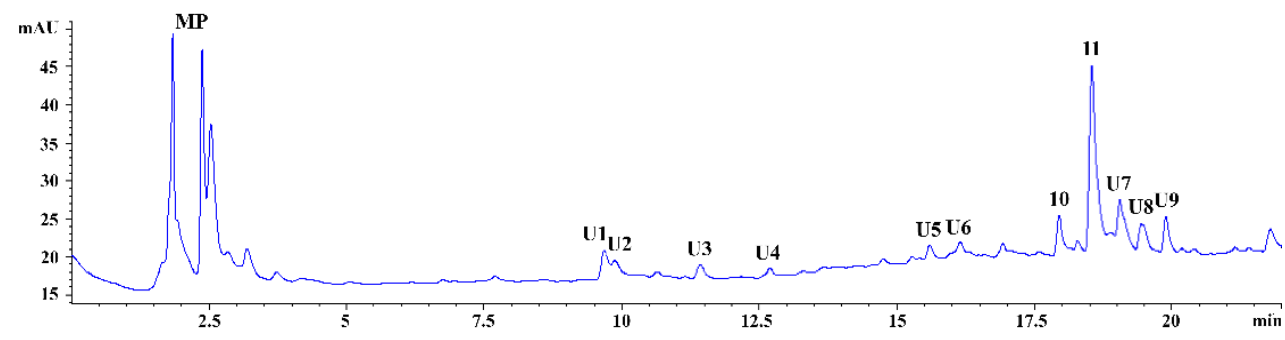

Figure 1. HPLC chromatogram of ethanol extract from Russula senecis.Peaks MP: mobile phase, 1: Cinnamic acid, 2: Pyrogallol; U1-10: Undetermined.

\subsection{Evaluation of antioxidative property.}

The antioxidative agent's strategy against different oxidant sources is not identical as the effect is exerted through different mechanisms such as binding with transition metal ions, inhibiting hydrogen abstraction, and quenching free radicals [27]. Hence, it is hard to forecast any investigating drug's potential by performing a single assay necessitating the employment of several methods based on different principles. Results of these experiments such as radical $\left(\mathrm{O}_{2}{ }^{\cdot-}, \mathrm{DPPH}^{\bullet}\right.$ and $\left.\mathrm{ABTS}^{\cdot+}\right)$ scavenging, inhibition of $\beta$-carotene bleaching, metal chelating effect, and electron donation ability (reducing power and total antioxidant capacity) have been summarized in Table 1.

\subsubsection{Radical scavenging activity.}

Firstly, superoxide radical scavenging assay was performed based on the investigated extract's capacity to render formazan development by quenching $\mathrm{O}_{2}{ }^{--}$generated in a riboflavinlight-NBT system [28]. Results showed that the percentage of $\mathrm{O}_{2}{ }^{--}$inhibition alleviated with increasing concentrations of the mushroom fraction. The preparation at dosages of 50,200, and $400 \mu \mathrm{g} / \mathrm{ml}$ hindered $7 \pm 0.24 \%, 35.87 \pm 1.89 \%$, and $65.53 \pm 1.41 \%$ radical formation, respectively illustrating an effect that was highly comparable with standard BHA (Figure 2a). The outcome demonstrated that the formulation was far better superoxide radical scavenger than extract from Pleurotus sajor-caju [29]. Subsequently, $\mathrm{DPPH}^{*}$ was used in the present work to measure the ability of the studied fraction to quench radical, reducing it to hydrazine, a bleached product [30]. As Figure $2 \mathrm{~b}$ revealed, the preparation quenched $1.96 \pm 0.02 \%$ and $31.69 \pm 0.58 \% \mathrm{DPPH}^{\circ}$ at the extents of 100 and $500 \mu \mathrm{g} / \mathrm{ml}$, respectively. When the level was increased to $1000 \mu \mathrm{g} / \mathrm{ml}$, the outcome amplified to $70.11 \pm 2.89 \%$, indicating concentration-wise radical scavenging capacity. Compared with the ethanolic formulation of Russula delica [31], results suggested that the extract under consideration showed excellent $\mathrm{DPPH}^{*}$ scavenging activity. A similar trend of behavior was also noted against $\mathrm{ABTS}^{\circ+}$, in that the blue/green radical was generated through a reaction between ABTS salt and potassium persulfate before reaction with putative 
antioxidant causing decolorization of solution [32]. The consequence of the method depicted that concerned fraction scavenged $15.57 \pm 1.11 \%, 35.08 \pm 1.89 \%$, and $59.11 \pm 2.58 \%$ radicals at the levels of 100,500 , and $1000 \mu \mathrm{g} / \mathrm{ml}$, respectively indicating steady-state function (Figure $2 \mathrm{c})$. However, the effect was lower than previously reported for the preparation from $R$. virescens [25]. Moreover, $\beta$-carotene bleaching assay was also performed to evaluate a substance's ability to prevent the pigment's oxidation, protecting it from free radicals generated during peroxidation of linoleic acid [33]. As evident from Figure 2d, bleaching inhibition activity of the studied extract ranged from $10 \pm 1.54 \%$ to $52.11 \pm 2.77 \%$ at the dosages of 50 and $400 \mu \mathrm{g} / \mathrm{ml}$, respectively, indicating better antioxidant effect than ethanol fractions from Calocybe gambosa, Armillaria mellea, Clitocybe odora, and Coprinus comatus [34].

\subsubsection{Reducing effect.}

Reducing the power of the investigating preparation was assessed using the potassium ferricyanide reduction method. The test sample resulted in converting $\mathrm{Fe}^{+3}$ to $\mathrm{Fe}^{+2}$ by donating hydrogen and changed the yellow color of the reaction mixture to green [35]. As shown in Figure $2 \mathrm{e}$, the reducing power of the formulation increased in a concentration-dependent manner. However, the effect was inferior to standard. At a level of $100 \mu \mathrm{g} / \mathrm{ml}$, the extract's activity was $0.08 \pm 0.01$, which was almost doubled when the dosage was augmented to 300 $\mu \mathrm{g} / \mathrm{ml}$. Thus, ethanol fraction from $R$. senecis presented more affinity for electron donation than Hypsizigus marmoreus [36], Lentinus edodes, Volvariella volvacea, Pleurotus eous, and Pleurotus sajor-caju [29]. Besides, the protocol of phosphomolybdate was also followed, being important in vitro assay to access total antioxidant capacity based on the conversion of colorless Mo (VI) to green phosphate Mo (V) by investigating drug [30]. Our findings showed that the ethanolic preparation holds good antioxidant potential than that of Termitomyces clypeatus [37], although inferior to hydro-ethanol formulation from $R$. senecis [12].

\subsubsection{Metal chelating ability.}

Also, $\mathrm{Fe}^{2+}$ chelating ability of the extract was also examined where the principal behind the assay was to decolorize iron-ferrozine complex by fraction ability. The concentration range from $10-200 \mu \mathrm{g} / \mathrm{ml}$, the metal-binding affinity of the preparation amplified from $7.62 \pm 0.08 \%$ to $78.8 \pm 2.49 \%$ in a concentration-dependent manner. However, beyond the dosages above, the outcome did not increase further as $78.9 \pm 3.12 \%$ iron-binding affinity was recorded (Figure $2 \mathrm{f}$ ). The effect was relatively determined to be superior to ethanol formulations from Catathelasma ventricosum, Stropharia rugoso-annulata, Clitocybe maxima, Craterellus cornucopioides, and Laccaria amethystea [38].

Fungi containing phenols are the subject of enhancing scientific interest as they provide natural security against free radicals, metal chelators, and pro-oxidants [8]. Recently phenolic acids and flavonoids have been recognized as powerful antioxidants owing to their perfect structural features. As a result, they are often supplemented to food as flavor, color, bitter and astringent, and maintain homeostasis from oxidation. Several epidemiological reports and associated analyses have consistently shown that these metabolites' consumption offers better protection against numerous chronic diseases [22]. Thus, attention on bio-resources enriched in phenolic substance is increasing as they can offer long-term health benefits. In this context, it should be taken into consideration that the potent antioxidant capacities of isolated fractions from $R$. senecis might be attributed mainly to its total phenol and flavonoid content. 


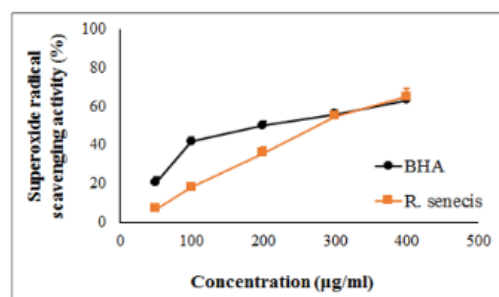

a

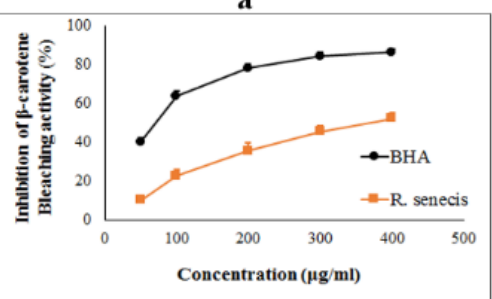

d
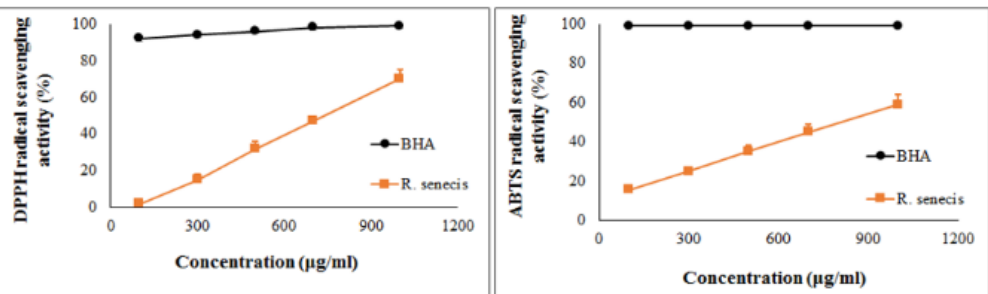

b

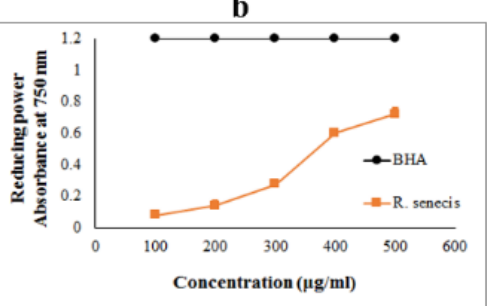

e

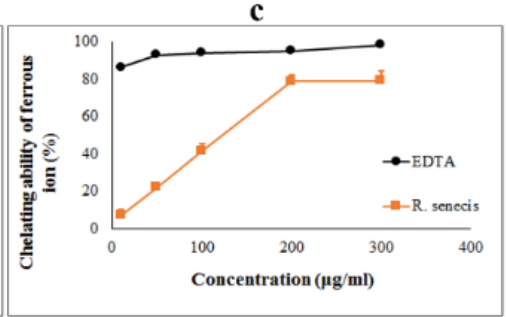

f

Figure 2. Antioxidant activity of ethanol fraction isolated from Russula senecis at different concentrations. (a) Superoxide, (b) DPPH and (c) ABTS radicals scavenging property (d) Inhibition of $\beta$-carotene bleaching (e) reducing power (f) chelating ability of ferrous ion.

Table 1. Antioxidant activity of ethanol fraction isolated from Russula senecis as represented by $\mathrm{EC}_{50}$ values $(\mu \mathrm{g} / \mathrm{ml})$ corresponding to $50 \%$ of the antioxidant activity or 0.5 of absorbance to reduce power assay. BHA was used as a standard in all assays except the chelating ability of ferrous ion and total antioxidant capacity methods

where EDTA and ascorbic acid were considered positive controls. In each row, dissimilar letters denote significant alterations between sample and standard $(p<0.05)$.

\begin{tabular}{|c|c|c|c|}
\hline & Antioxidant parameters & Ethanol extract & Standard \\
\hline \multirow{6}{*}{$\begin{array}{l}\mathrm{EC}_{50} \\
\text { value }\end{array}$} & Scavenging ability of superoxide radical & $272.5 \pm 7.5^{\mathrm{a}}$ & $218 \pm 10^{\mathrm{b}}$ \\
\hline & Scavenging ability of DPPH radical & $738.81 \pm 18^{\mathrm{a}}$ & $7.45 \pm 0.02^{\mathrm{b}}$ \\
\hline & Scavenging ability of ABTS radical & $806.57 \pm 34.1^{\mathrm{a}}$ & $3.65 \pm 0.02^{\mathrm{b}}$ \\
\hline & Inhibition of $\beta$-carotene bleaching & $457.5 \pm 70^{\mathrm{a}}$ & $39.25 \pm 1.54^{\mathrm{b}}$ \\
\hline & Reducing power & $437.1 \pm 2.5^{\mathrm{a}}$ & $32.21 \pm 6.91^{\mathrm{b}}$ \\
\hline & Chelating ability of ferrous ion & $122.4 \pm 8.2^{\mathrm{a}}$ & $2.54 \pm 0.52^{\mathrm{b}}$ \\
\hline \multicolumn{2}{|c|}{$\begin{array}{l}\text { Total antioxidant activity ( } \mu \mathrm{g} \text { ascorbic acid equivalent } / \mathrm{mg} \\
\text { of dry extract) }\end{array}$} & $8.65 \pm 2.84$ & Not applicable \\
\hline
\end{tabular}

\subsection{Estimation of antibacterial potential.}

In addition to the antioxidant effect, the antibacterial potency of the formulation was evaluated against six microorganisms using the microplate technique. The fraction presented excellent growth inhibitory potential against all tested pathogens, especially the Gram-negative one. As depicted in Table 2, S. aureus and E. coli were found to be the most susceptible bacteria as minimum inhibitory concentration (MIC) values were comparatively in a lesser extent, though the effect was found to be about eight times inferior to the standard. The preparation was also able to suppress the viability of $B$. subtilis and L. monocytegenes where concentrations below $350 \mu \mathrm{g} / \mathrm{ml}$ were enough for retarding $50 \%$ bacterial survival. Contrarily moderate antibiotic activity was recorded against $S$. typhimurium and $K$. pneumoniae, as evident by high MIC scores indicating their quite resistant nature towards the studied formulation. Overall, the extract from $R$. senecis presented better potency than ethanol fractions from Cordyceps sinensis, Laricifomes officinalis, Oudemensiella mucida, Coprinus comatus [39], and Ramaria flava [40].

Regarding antibacterial action, it is expected to see the low activity of the preparation against tested Gram-negative species. Since the presence of hard-to-penetrate outer membrane and constitutively overexpressed efflux pumps enable these microbes much more challenging to target with herbal formulations than Gram-positive pathogens [3]. However, the efficiency of these fractions against the susceptible bacteria could in part be because of their phenolic composition, such as cinnamic acid and flavonoid [41]. It has been conveyed that such action 
of phenolics is related to interaction with enzymes, adsorption to cell membranes, substrate, and metal ion deprivation [42]. Thus phenolic compounds are now used as a supplement during antibiotic therapy. In that matrices, $R$. senecis ethanol preparation can be considered as an effective candidate.

Table 2. Antibacterial activity of ethanol fraction isolated from Russula senecis as represented by MIC value $(\mu \mathrm{g} / \mathrm{ml})$. Streptomycin was used as a positive control. In each row, dissimilar letters denote significant alterations between sample and standard $(p<0.05)$.

\begin{tabular}{l|l|l|l} 
Type of bacteria & Name of bacteria & Ethanol extract & Streptomycin \\
\hline \multirow{4}{*}{ Gram positive } & Listeria monocytogenes & $320 \pm 8.48^{\mathrm{a}}$ & $4.68 \pm 0.17^{\mathrm{b}}$ \\
\cline { 2 - 4 } & Staphylococcus aureus & $48.5 \pm 2.63^{\mathrm{a}}$ & $6.29 \pm 0.16^{\mathrm{b}}$ \\
\cline { 2 - 4 } & Bacillus subtilis & $250 \pm 1.89^{\mathrm{a}}$ & $5.61 \pm 0.01^{\mathrm{b}}$ \\
\hline \multirow{4}{*}{ Gram negative } & Escherichia coli & $48.7 \pm 2.99^{\mathrm{a}}$ & $5.41 \pm 0.11^{\mathrm{b}}$ \\
\cline { 2 - 4 } & Salmonella typhimurium & $461 \pm 5.68^{\mathrm{a}}$ & $5.09 \pm 0.03^{\mathrm{b}}$ \\
\cline { 2 - 4 } & Klebsiella pneumonia & $529 \pm 6.81^{\mathrm{a}}$ & $5.29 \pm 0.14^{\mathrm{b}}$
\end{tabular}

\subsection{Determination of anticancer activity.}

Uncontrolled cellular growth is a hallmark of cancer. Thus, targeting apoptosis, a common form of cell death, is considered the most successful non-surgical strategy for treatment. Indeed apoptosis per se is an exceedingly controlled process in vertebrates that eliminates old, superfluous, undesired, or potentially dangerous cells during development, inhibiting carcinogenesis. Since cancer is master at evading such programmed suicidal pathway, scientists are looking for outside stimuli capable of activating the machinery [43]. From that time, a significant number of methods have been postulated to estimate the potency of drugs that can trigger apoptotic cascades selectively in carcinoma. In this context, permanent cell lines are considered the most suitable in vitro model systems due to their immortal nature and reproducible growth behavior [44].

\subsubsection{Cytotoxicity, clonogenic cell survival and wound healing assays.}

To define cancer cells' destiny after incubation with different concentrations of ethanol extract from $R$. senecis, we investigated the drug's effect on Hep3B cell metabolism. Results of WST-8 method, based on the formation of yellow-colored formazan dye by dehydrogenase activities of live cells, showed a remarkable inhibition on the survival rate of liver hepatoma. As such, the fraction at the level of 100 and $300 \mu \mathrm{g} / \mathrm{ml}$ rendered cell proliferation by $17.5 \pm 1.05 \%$ and $46.13 \pm 2.56 \%$, respectively, within $24 \mathrm{~h}$ exposure. A similar potency trend was also observed at higher concentrations as treatment at the level of $500 \mu \mathrm{g} / \mathrm{ml}$ augmented cell death to $57.7 \pm 2.1 \%$, indicating dose-wise action (Figure $3 \mathrm{a}$ ). The data helped us to calculate half-maximal inhibitory concentration ( $\mathrm{IC}_{50}$ ) enumerated to be $367.21 \pm 2.5 \mu \mathrm{g} / \mathrm{ml}$, which was lesser than that of Inonotus obliquus [45] and Russula alatoreticula [8], portraying a more aggressive nature of the studied fraction against Hep3B. Comparative treatment of the preparation on a regular liver cell line (BRL-3A) revealed no cytotoxicity even at the highest investigated dose confirming harmful action of the studied formulation selectively towards cancer cells.

To decode whether the extract shows a sign of cytostatic or cytocidal growth inhibitory effect, clonogenic survival assay was monitored that regulated reproductive capability of challenged liver hepatoma to form a clone or large colony. As illustrated in Figure $3 \mathrm{~b}$, the growth curves of untreated Hep3B cultured in DMEM or media supplemented with $0.05 \%$ DMSO were not affected. Similarly, sufficient cell proliferation was also recorded after 
exposure to $200 \mu \mathrm{g} / \mathrm{ml}$ concentration of the fraction. Nonetheless, when challenged with 300 and $400 \mu \mathrm{g} / \mathrm{ml}$ for $24 \mathrm{~h}$, reduced adhesion property, survival skill, and cloning efficiency were noticed. The effect was not reversed even after growth in a drug-free condition for two weeks, indicating that the treated cells completely lost cell division ability. Based on outputs, the quantities of 200,300 , and $400 \mu \mathrm{g} / \mathrm{ml}$ of the studied preparation were used for other anticancer experimentations.

In addition to these proliferation and survival assays, the impact of the formulation on growth and/or migration of Hep3B cells was also analyzed by adopting a wound healing test. Subsequent to creating a scratch/wound, cells in the control dish were witnessed to migrate to occupy the free space (Figure 3c). Thus control HCC cells after $24 \mathrm{~h}$ reached greater confluence, which was quite the opposite to the treated condition irrespective of experimental doses. Indeed a slight reduction in re-epithelialization was observed in exposure to $200 \mu \mathrm{g} / \mathrm{ml}$ of the extract whereby cells incubated with higher levels did not significantly populate the wounded area. Overall observations led to the consensus that fraction from $R$. senecis possesses in vitro cytotoxic and anti-proliferative potency towards the Hep3B liver cancer cell line.

\subsubsection{Assessment of cellular and nuclear morphology.}

To resolve if the observed decline in cell viability was tempted by apoptosis, morphological studies were carried out as the tightly regulated process is characterized by certain phenotypic alterations. Observation under the optically inverted light microscope depicted that the negative control cells possessed original morphology such as normal round shape, consistent size is strongly attached. In comparison, the treated cells were notably destructed as they appeared smaller and shrunken, where interaction with nearby cells was damaged. When cells were exposed to higher concentrations, they gradually became more contracted, accompanied by a significant loss in cell number (Figure 4a). Consistently change in nuclear morphology of liver carcinoma in the presence or absence of the extract was also noticed using DAPI staining and fluorescence microscopy. Results showed that DAPI positive HCC cells and their intensities amplified in a dose-dependent manner compared to the control group. This indicated that nuclei with chromatin condensation and apoptotic bodies were formed upon exposure to fraction from $R$. senecis, particularly at higher doses. Besides, membrane blebbing and fragmented nuclear bodies were recorded. They indicated the potency of the preparation from $R$. senecis to trigger programmed cell death in cancer cells.

To further contrast between live and dead cells visually, dual staining with AO and EB was performed where live cells fluoresce green due to AO uptake. In contrast, EB stains double-stranded DNA of dead cells that have decreased plasma membrane integrity. On the other hand, late apoptotic and necrotic cells appear orange and red, respectively [19]. In our experiment, living cells with normal morphology were observed in the control group owing to green fluorescence (Figure 4b). Whereas in the experimental set, more cells were EB positive and showed yellow-green fluorescence, indicating an early apoptotic phase, and in a higher dose, the amount of apoptotic cells increased with orange margination around the cells. These emblematic shapes of biological differences visually confirmed that extract from $R$. senecis induced apoptosis in HCC cells. 

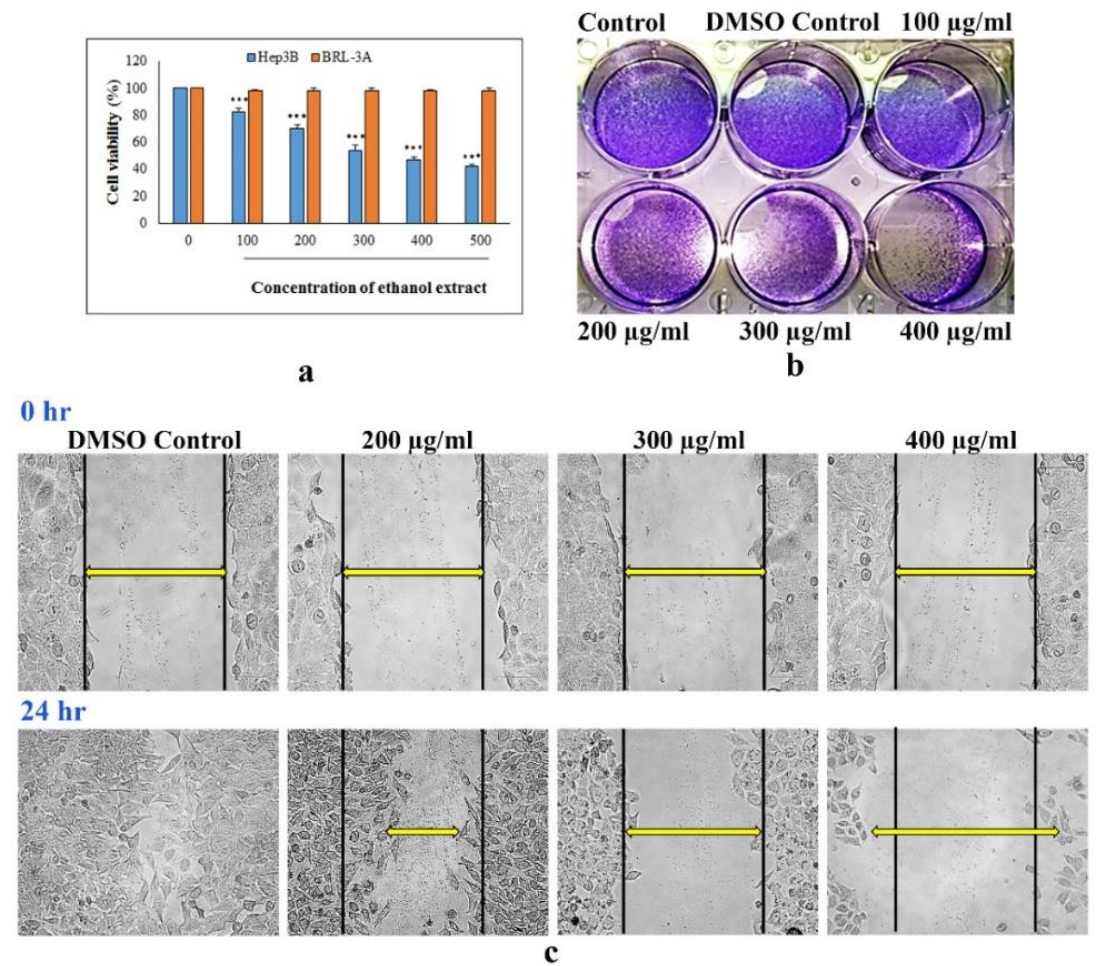

Figure 3. Ethanol extract from Russula senecis inhibits Hep3B cell proliferation. (a) Results of WST assay showed that cancer cell numbers reduced drastically due to the $24 \mathrm{~h}$ treatment in a dose-wise pattern, although no cytotoxic effect was detected on non-cancerous cell, BRL-3A at those investigated concentrations. The treated condition's cell viability was compared by ANOVA post-hoc Tukey's test- ***p< 0.001 vs. control. (b) The Colony-formation method was performed by treating cancer cells with increasing levels of ethanol preparation. The outcome demonstrated a concentration-dependent decrease in proliferation of Hep3B cells in the presence of the formulation. (c) The effect of ethanol extract on Hep3B cell migration was determined by using a woundhealing technique. Cells were cultured in a monolayer in 12 well plates, and an artificial gap was created. The rate of cell migration to close the scratch was analyzed after $24 \mathrm{~h}$ incubation and photographed under a microscope. The bold lines define gap areas of artificial wounds. Images represent the best of replicates $(n=3)$.
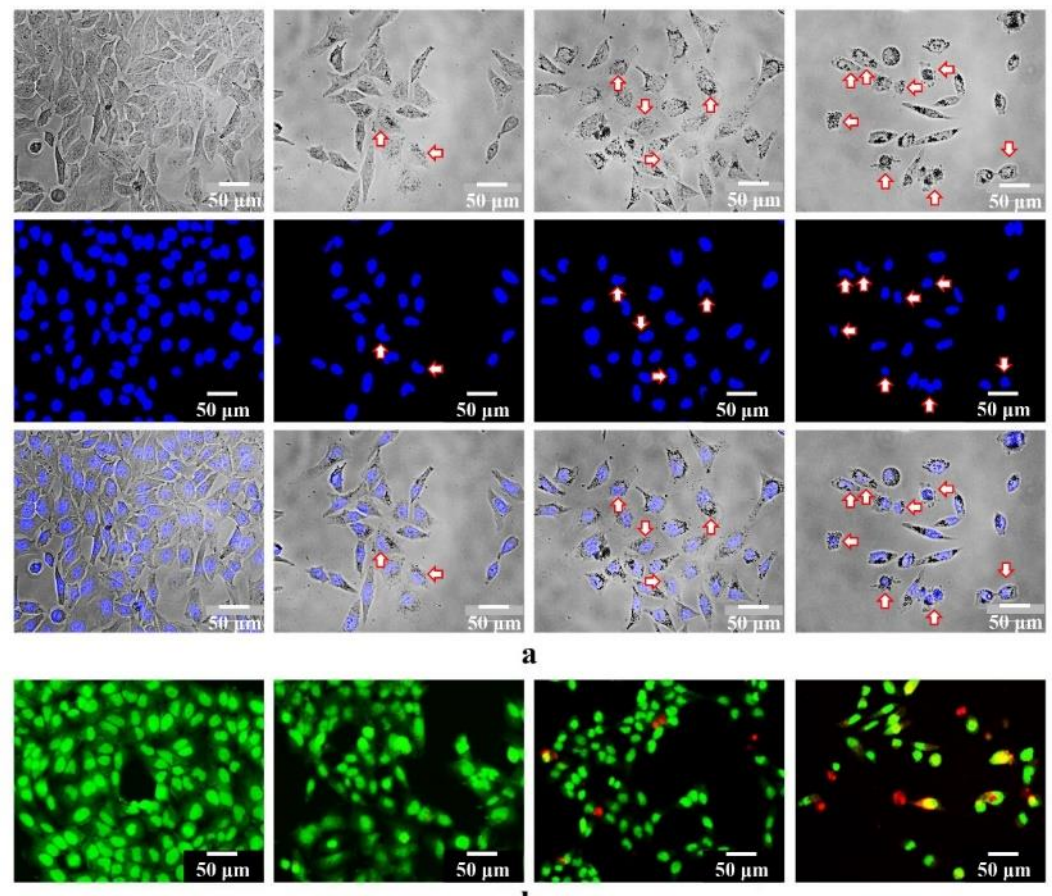

Figure 4. Effect of ethanol extract from Russula senecis on cellular and nuclear morphology of Hep3B. The cells were incubated with the fraction for indicated concentrations for $24 \mathrm{~h}$ and then visualized using (a) DAPI or (b) acridine orange/ethidium bromide staining with the help of a fluorescent microscope. The arrows show cell shrinkage, nuclear condensation, and fragmentation. 


\subsubsection{Cell cycle analysis.}

To explore whether the extract induced apoptosis was associated with anomalies in the cell cycle, we measured DNA content of HCC cells in different phases using flow cytometry. It was clear from the results that with an increase in the fraction concentration, the percentage of cells in resting or initial (G0/G1), DNA replication (S), and post replication (G2/M) phases decreased (Figure 5a). On the other hand, the cell population at the sub-G0 phase, indicative of apoptotic cells, increased significantly compared to the untreated controls. Thus, the finding lets us assume that growth inhibition induced by the studied formulation from R. senecis was through the arrest of cell cycle progression at the sub-G0/G1 phase. The observation could be justified as the treatment might cause sufficient DNA fragmentation resulting in apoptotic cells with lesser DNA than healthy cells.

\subsubsection{Detection of DNA fragmentation by TUNEL assay.}

Indeed, degradation of DNA into oligo-nucleosomal-sized fragments is a unique incident in apoptosis. Hence, several DNA strand breaks before and following exposure to the formulation from $R$. senecis was compared using TUNEL assay. As shown in Figure $5 \mathrm{~b}$, the healthy untreated cells did not possess any significant DNA fragmentation, while the event was prominent in treated conditions. The DNA fragmentation index (DFI) scores, representing damaged DNA, augmented steadily with an increase of the fraction concentration, where it reached a maximal level of $61.3 \pm 1.15 \%$ in the presence of the highest investigating dose. Consequently, earlier studies have corroborated DNA strand breaks with mitochondrial ROS production beyond a threshold level, resulting in oxidative stress damaging cellular components and affecting cell survival [46].

\subsubsection{Measurement of intracellular ROS and MMP.}

Cancer cells are highly sensitive to mitochondrial function such as hyper ROS generation due to antioxidant mechanisms' insufficiency. As such, some chemotherapeutics' intracellular accumulation of these reactive molecules is one of the most important strategies for inducing apoptosis of carcinoma cells [47]. To determine if treatment with the studied preparation affected ROS generation, these free radicals' intracellular level was identified using dye DCFDA, which forms highly fluorescent $2^{\prime}, 7^{\prime}$-dichlorofluorescein (DCF) in the presence of ROS. Our results suggest that co-incubation of HCC with the extract did enhance ROS synthesis inside Hep3B as early as $30 \mathrm{~min}$ of exposure. Treatment with the extract at concentrations of 200 and $400 \mu \mathrm{g} / \mathrm{ml}$ caused a significant increase in ROS extents by $13.55 \pm 2.54 \%$ and $32.68 \pm 2.88 \%$, respectively, when compared to the control group (Figure 5c). Thus the results suggested that the fraction might provide an opportunistic contrivance to kill hepatocellular carcinoma by imposing a rapid and robust ROS level increase.

Excessive ROS production causes loss of mitochondrial permeability, which is characteristic of activation of the intrinsic apoptotic pathway. To assess whether the formulation affects mitochondrial function, the potential alteration in the mitochondrial membrane was analyzed by employing JC-1. This dye indicates the collapse of MMP. According to the results, MMP reduction was encountered due to treatment of the ethanol extract dose-dependently, as evident by a gradual decline in fluorescence (MMP peak shifted to left) (Figure 5d). The outcome presented that upon exposure of $400 \mu \mathrm{g} / \mathrm{ml}$ concentration of 
the fraction, MMP was lost by $45.49 \pm 3.98 \%$ regarding control cells suggesting a mechanism of action via mitochondria.

3.4.6. Analysis of apoptosis-related gene expression and elucidation of the mode of action.

Mitochondrial outer membrane permeabilization is the point of no return in apoptotic cell death. Such cellular decision to initiate the cascade is consecutively controlled by a delicate balance between pro-and anti-apoptotic molecules of the Bcl-2 family. The typical group member, i.e., Bcl-2 is mainly located in nuclear, mitochondrial, and endoplasmic reticulum membranes.
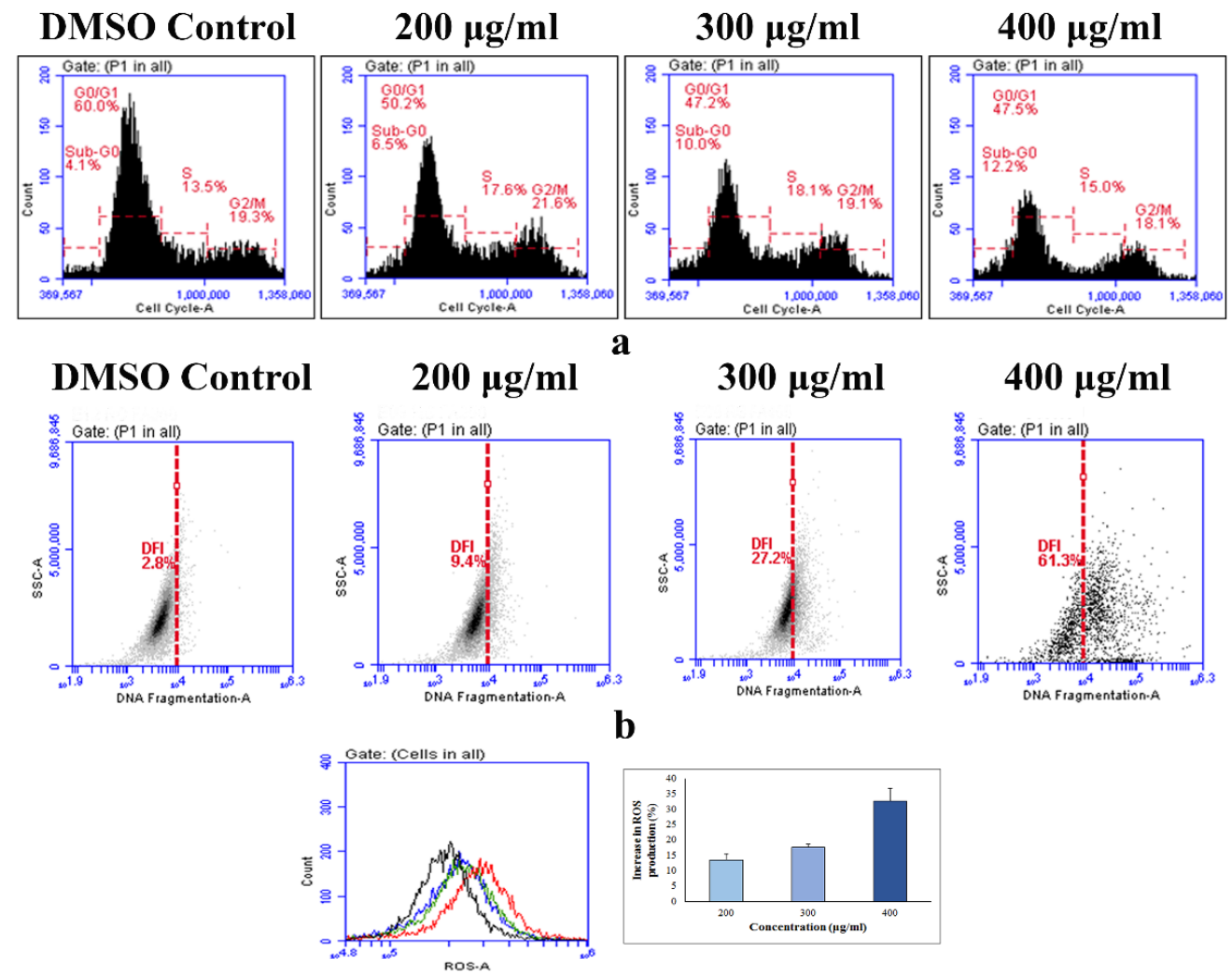

b
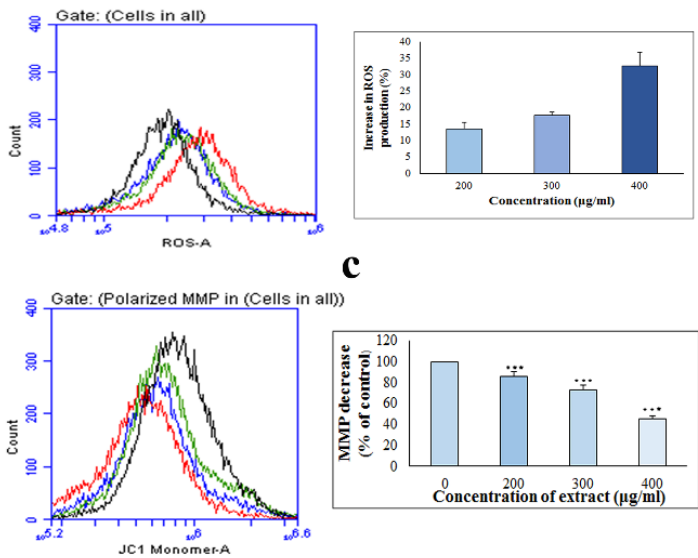

d

Figure 5. Effect of ethanol extract from Russula senecis on cell cycle distribution, DNA fragmentation, intracellular ROS generation, and mitochondrial membrane polarization of Hep3B cells. (a) Represents flow cytometric profiles of DMSO control and fraction at a range of concentrations (b) The studied preparation induced DNA fragmentation of Hep3B cells as detected by cytometry using TUNEL assay. (c) ROS generation was determined by flow cytometry using DCFDA following treatment of different concentrations of the formulation such as 200 (blue), 300 (green), and $400 \mu \mathrm{g} / \mathrm{ml}$ (red) in contrast to control cells (black). The outcome was depicted graphically. (d) Reduction in MMP was determined by flow cytometry using JC-1 dye following treatment of different concentrations of the extract such as 200 (green), 300 (blue), and $400 \mu \mathrm{g} / \mathrm{ml}$ (red) in contrast to control cells (black). The outcome was depicted graphically. 
However, the family members that promote apoptosis, represented by Bax, are mainly located in the cytoplasm. Following a death signal, relative expression of pro-and antiapoptotic Bcl-2 proteins is modified, resulting in enhancement of pro-apoptotic Bax over antiapoptotic Bcl-2. In turn, the phenomenon activates caspases, a conserved group of enzymes that conclusively commit a cell to die [48]. Thus, to have a clear-cut idea of the studied fraction mode of action, gene expression analyses were performed. The outcome indicated a dosedependent increase in mRNA expression of Bax. Bcl-2, however, was found to be downregulated compared to untreated controls. Further investigation of downstream effector caspases showed a dose-dependent increase in caspase-9 (Figure 6a-d).

The essential onco-therapeutic stratagem is to induce apoptosis in cancer cells, divided into the extrinsic or the mitochondria-dependent pathways. In our ongoing efforts to determine ethanol extract's apoptotic mechanism on Hep3B cells, we focused on the mitochondrial pathway. Overall, our data demonstrated that the extract increased mitochondrial accumulation of ROS, which triggered enhancing permeability of the mitochondrial membrane. The phenomenon finally triggered Bax's expression but decreased $\mathrm{Bcl}-2$, shifting Bax/Bcl-2 ratio, which then activated caspase-9 (Figure 6e).

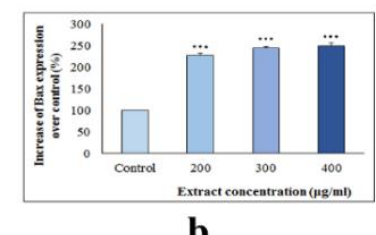

b
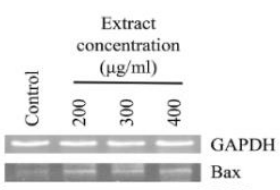

Bax

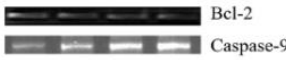

$\mathbf{a}$

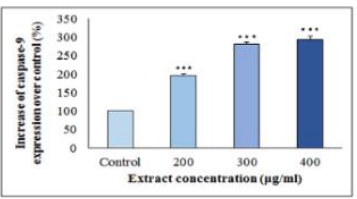

d

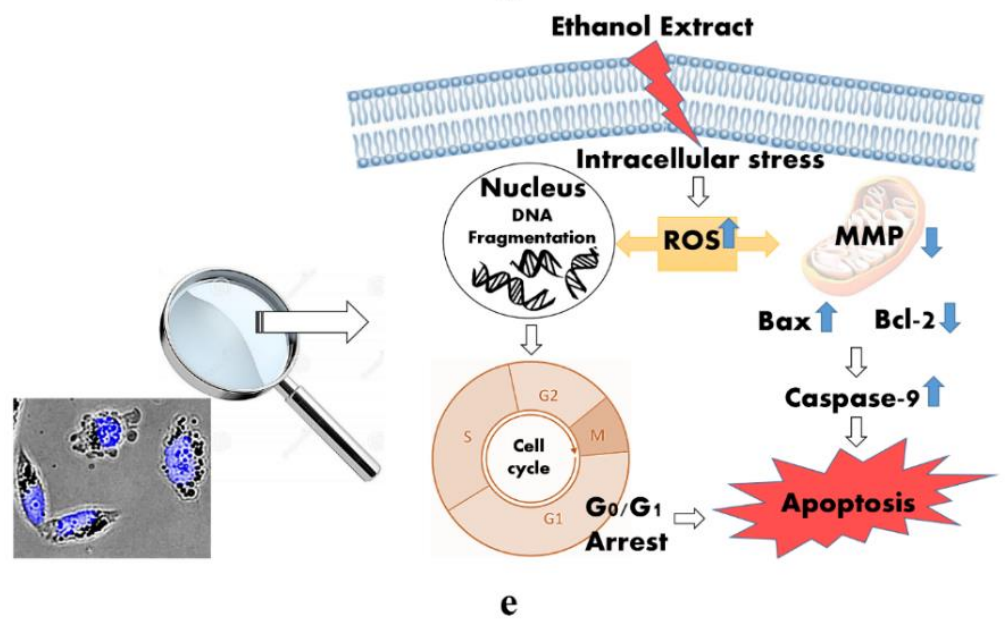

Figure 6. Insight into the molecular mechanism of ethanol extract from Russula senecis on hepatoma. (a) Total RNA was isolated from Hep3B cells after $24 \mathrm{~h}$ treatment. RT-PCR was performed to signify a change in the transcription level of three different genes (b) Bax (c) Bcl-2 (d) Caspase-9, where GAPDH was considered as a housekeeping gene. (e) The schematic diagram represents the anticancer activity of the studied fraction mediated through the intrinsic mitochondrial pathway. The research demonstrated that the fraction unveiled prominent anticancer property evident by morphological changes, cell cycle interference, MMP depletion, and ROS augmentation through Bax, Bcl-2, and caspase-9 intrinsic mitochondrial pathway. 
Recent scientific evaluation on mushrooms, especially from the Far East area, has confirmed extracts' efficacy in inhibiting the proliferation of various cancer cell lines [49]. The desired effect might be attributed to phenolic compounds like cinnamic acid derivatives. They can down modulate carcinogenesis by activating pro-apoptotic proteins, e.g., caspases, Bcl-2 family members, and/or inhibiting anti-apoptotic proteins [50]. Hence, such natural resources may offer new avenues for oncology, contributing novel drugs with highly specific anti-tumor activities and low toxicity. The effort can provide us alternatives that can either independently substitute chemopreventive medicines or act with other drugs synergistically, reducing the need for synthetic pills.

\section{Conclusions}

Collectively, the studied fraction from $R$. senecis presented excellent antioxidant activities where $\mathrm{EC}_{50}$ values were in the decreasing order of chelating ability of $\mathrm{Fe}^{2+}>$ inhibition of $\mathrm{O}_{2}{ }^{*-}$ generation $>$ reducing power $>$ retardation of $\beta$-carotene bleaching $>$ quenching effect on $\mathrm{DPPH}^{*}>$ scavenging ability of $\mathrm{ABTS}^{*+}$. The extract also exhibited a broad spectrum of antibiotic activity as it hindered all the tested bacterial cell growth, particularly Gram-positive ones. Comparative analysis revealed that $S$. aureus and E. coli were the most susceptible microorganisms compared to $K$. pneumoniae exhibiting quite resistant nature. However, the main highlight of this research was exploring the anticancer property of preparation under investigation, being the first report on $R$. senecis, to the best of our knowledge. The obtained results provided strong experimental evidence for selective cytotoxic activity of the formulation towards Hep3B cells. The anti-proliferative response was found to be mediated by disruption of redox balance, cell cycle arrest, breakdown of mitochondrial membrane potential, induction of DNA fragmentation, alteration of $\mathrm{Bax} / \mathrm{Bcl}-2$ ratio, activation of caspase- 9 , which triggered drug-induced apoptosis in liver cancer cells. Such a diverse range of bioactivities could be attributed to valuable secondary metabolites present in the extract, for instance, phenolic compounds (pyrogallol> cinnamic acid), ascorbic acid, and carotenoids. All in all, the research recommends the use of $R$. senecis in the food, pharmaceutical, and wellness industries in order to find a natural way to address significant medical problems. The endeavor can also awaken interest in foraging and selling mushrooms, which may change our country from a mycophobic to mycophilic society boosting rural empowerment.

\section{Funding}

This research received no external funding.

\section{Acknowledgments}

The authors would like to acknowledge the facilities provided by the Department of Botany (UGC-CAS Phase VI, VII), University of Calcutta, and DST-FIST for instrumental support.

\section{Conflicts of Interest}

The authors declare no conflict of interest.

\section{References}

1. Neha, K.; Haider, M.R.; Pathak, A.; Yar, M.S. Medicinal prospects of antioxidants: A review. Eur. J. Med. Chem.2019, 178, 687-704, https://doi.org/10.1016/j.ejmech.2019.06.010. 
2. Lourenço, S.C.; Moldão-Martins, M.; Alves, V.D. Antioxidants of natural plant origins: from sources to food industry applications. Molecules 2019, 24, https://doi.org/10.3390/molecules24224132.

3. Khan, M.F.; Tang, H.; Lyles, J.T.; Pineau, R.; Mashwani, Z.; Quave, C.L. Antibacterial properties of medicinal plants from Pakistan against multidrug-resistant ESKAPE pathogens. Front. Pharmacol. 2018,9, https://doi.org/10.3389/fphar.2018.00815.

4. Angiolella, L.; Sacchetti, G.; Efferth, T. Antimicrobial and antioxidant activities of natural compounds. Evid. Based Complement. Alternat. Med.2018,2018, https://doi.org/10.1155/2018/1945179.

5. Yang, J.D.; Hainaut, P.; Gores, G.J; Amadou, A.; Plymoth, A.; Roberts, L.R. A global view of hepatocellular carcinoma: trends, risk, prevention and management. Nat. Rev. Gastroenterol. Hepatol.2019,16, 589-604, https://doi.org/10.1038/s41575-019-0186-y.

6. Abdel-Hamid, N.M.; Abass, S.A.; Mohamed, A.A.; Hamid, D.M. Herbal management of hepatocellular carcinoma through cutting the pathways of the common risk factors. Biomed. Pharmacother. 2018,107, 1246-1258, https://doi.org/10.1016/j.biopha.2018.08.104.

7. Devi, M.R.; Krishnakumari, S. Qualitative screening of phytoconstituents of Pleurotus sajor caju (Fries sing) and comparison between hot and cold-aqueous and silver nanoparticles extracts. J. Med. Plants Stud.2015, 3, 172-176.

8. Khatua, S.; Chandra, S.; Acharya, K. Expanding knowledge on Russula alatoreticula, a novel mushroom from tribal cuisine, with chemical and pharmaceutical relevance. Cytotechnology2019, 71, 245-259, https://doi.org/10.1007/s10616-018-0280-y.

9. Hong, S.W.; Jung, H.S. Fleshly Basidiomycetes in Mt. Jogye. Korean J. Bot.1977, 20, $29-38$.

10. Wu, F.; Zhou, L.W.; Yang, Z.L.; Bau, T.; Li, T.H.; Dai, Y.C. Resource diversity of Chinese macrofungi: edible, medicinal and poisonous species. Fungal Divers. 2019, 98, 1-76, https://doi.org/10.1007/s13225019-00432-7.

11. Natarajan, K.; Senthilarasu, G.; Kumaresan, V.; Riviere, T. Diversity in ectomicorrhizal fungi of a dipterocarp forest in Western Ghats. Curr. Sci. 2005, 88, 1893-1895.

12. Khatua, S.; Dutta, A.K.; Acharya, K. Russula senecis: A delicacy among the tribes of West Bengal. PeerJ2015, 3, https://doi.org/10.7717/peerj.810.

13. Khatua, S.; Acharya, K. Alkaline extractive crude polysaccharide from Russula senecis possesses antioxidant potential and stimulates innate immunity response. J Pharm Pharmacol2017, 69, 1817-1828.

14. Khatua, S.; Acharya, K. Water soluble antioxidative crude polysaccharide from Russula senecis elicits TLR modulated NF- $\mathrm{KB}$ signalling pathway and pro-inflammatory response in murine macrophages. Front. Pharmacol.2018, 9,https://doi.org/10.3389/fphar.2018.00985.

15. Khatua, S.; Sikder, R.; Acharya, K. Chemical and biological studies on a recently discovered edible mushroom: a report. FABAD J. Pharm. Sci. 2018, 43, 151-157.

16. Martinez, A.C.; Marcelo, E.L.; Marco, A.O.; Moacyr, M. Differential responses of superoxide dismutase in freezing resistant Solanum curtibolum and freezing sensitive Solanum tuberosum subjected to oxidative and water stress. Plant Sci. 2001, 160, 505-515,https://doi.org/10.1016/s0168-9452(00)00418-0.

17. Khatua, S.; Ghosh, S.; Acharya, K. Antioxidant properties and metabolites profiling of polyphenol rich fraction from a folk mushroom, Macrocybe lobayensis, using different extractant. Int. J. Pharm. Sci. Res.2019, 10, 564-571.

18. Khatua, S.; Acharya, K. Functional ingredients and medicinal prospects of ethanol extract from Macrocybe lobayensis. Pharmacogn. J. 2018, 10, 1154-1158,https://doi.org/10.5530/pj.2018.6.197.

19. Khatua, S.; Sen Gupta, S.; Ghosh, M.; Tripathi, S.; Acharya, K. Exploration of nutritional, antioxidative, antibacterial and anticancer status of Russula alatoreticula: towards valorization of a traditionally preferred unique myco-food. J. Food Sci. Technol. 2020, in press,https://doi.org/10.1007/s13197-020-04723-9.

20. Badalyan, S.M.; Barkhudaryan, A.; Rapior, S. Recent progress in research on the pharmacological potential of mushrooms and prospects for their clinical application. In:Medicinal Mushrooms. Agrawal, D.C.; Dhanasekaran, M. (eds.), Springer Nature Singapore Pte Ltd. 2019; pp 1-70,https://doi.org/10.1007/978981-13-6382-5_1.

21. Zilani, M.N.H.; Uddin, S.J.; Hossain, H.; Hazni, H.; Shilpi, J.A.; Hossain, M.G. Chemical characterization and bioactivity of Trichosanthes dioica edible shoot extract. Orient Pharm. Exp. Med.2018, 18, 167175,https://doi.org/10.1007/s13596-018-0310-5.

22. Tungmunnithum, D.; Thongboonyou, A.; Pholboon, A.; Yangsabai, A. Flavonoids and other phenolic compounds from medicinal plants for pharmaceutical and medical aspects: An overview. Medicines 2018, 5, https://doi.org/10.3390/medicines5030093.

23. Morel, S.; Arnould, S.; Vitou, M.; Boudard, F.; Guzman, C.; Poucheret, P.; Fons, F.; Rapior, S. Antiproliferative and antioxidant activities of wild Boletales mushrooms from France. Int. J. Med. Mushrooms2018, 20, 13-29,https://doi.org/10.1615/IntJMedMushrooms.2018025329.

24. Feleke, H.T.; Doshi, A. Antimicrobial activity and bioactive compounds of Indian wild mushrooms. Indian J. Nat. Prod. Resour. 2017, 8, 254-262.

25. Hasnat, M.A.; Pervin, M.; Debnath, T.; Lim, B.O. DNA Protection, Total phenolics and antioxidant potential of the mushroom Russula virescens. J. Food Biochem. 2013, 38, 6-17. 
26. Sheikh, I.A.; Vyas, D.; Ganaie, M.A.; Dehariya, K.; Singh, V. HPLC determination of phenolics and free radical scavenging activity of ethanolic extracts of two polypore mushrooms. Int. J. Pharm. Pharmaceutic. Sci.2014, 6, 679-684.

27. Huyut, Z.; Beydemir, F.; Gülçin, E. Antioxidant and antiradical properties of selected flavonoids and phenolic compounds. Biochem. Res. Int. 2017, 2017, https://doi.org/10.1155/2017/7616791.

28. Saha, S.; Khatua, S.; Paloi, S.; Acharya, K. Antioxidant and nitric oxide synthase activation properties of water soluble polysaccharides from Pleurotus florida. Int. J. Green Pharm. 2013, 7, 182-188.

29. Boonsong, S.; Klaypradit, W.; Wilaipuna, P. Antioxidant activities of extracts from five edible mushrooms using different extractants. Agricul. Natur. Resour. 2016, 50, 8997,https://doi.org/10.1016/j.anres.2015.07.002.

30. Batool, R.; Khan, M.R.; Sajid, M.; Ali, S.; Zahra, Z. Estimation of phytochemical constituents and in vitro antioxidant potencies of Brachychiton populneus (Schott \& Endl.) R.Br. BMC Chem. 2019, 13, https://doi.org/10.1186/s13065-019-0549-z.

31. Yaltirak, T.; Aslim, B.; Ozturk, S.; Alli, H. Antimicrobial and antioxidant activities of Russula delica Fr. Food Chem. Toxicol. 2009, 47, 2052-2056,https://doi.org/10.1016/j.fct.2009.05.029.

32. Formagio, A.S.N.; Volobuff, C.R.F.; Santiago, M.; Cardoso, C.A.L.; Vieira, M.C.; Pereira, Z.V. Evaluation of antioxidant activity, total flavonoids, tannins and phenolic compounds in Psychotria leaf extracts. Antioxidants2014, 3, 745-757,https://doi.org/10.3390/antiox3040745.

33. Alam, M.N.; Bristi, N.J.; Rafiquzzaman, M. Review on in vivo and in vitro methods evaluation of antioxidant activity. Saudi Pharm. J.2013, 21, 143-152,https://doi.org/10.1016/j.jsps.2012.05.002.

34. Vaz, J.A.; Barros, L.; Martins, A.; Santos-Buelga, C.; Vasconcelos, M.H.; Ferreira, I.C.F.R. Chemical composition of wild edible mushrooms and antioxidant properties of their water soluble polysaccharidic and ethanolic fractions. Food Chem. 2011, 126, 610-616,https://doi.org/10.1016/j.foodchem.2010.11.063.

35. Jayakumar, T.; Thomas, P.A.; Sheu, J.R.; Geraldine, P. In-vitro and in-vivo antioxidant effects of the oyster mushroom Pleurotus ostreatus. Food Res. Int. 2011, 44, 851861,https://doi.org/10.1016/j.foodres.2011.03.015.

36. Lee, Y-L.; Yen, M-T.; Mau, J-L. Antioxidant properties of various extracts from Hypsizigus marmoreus. Food Chem. 2007, 104, 1-9. https://doi.org/10.1016/j.foodchem.2006.10.063.

37. Mitra, P.; Mandal, N.C.; Roy, A.; Acharya, K. Phytochemical study and antioxidative property of ethanolic extract from Termitomyces clypeatus. J. Appl. Pharma. Sci.2016, 6, 120-124, https://doi.org/10.7324/JAPS.2016.60718.

38. Liu, Y.T.; Sun, J.; Luo, Z.Y.; Rao, S.Q.; Su, Y.J.; Xu, R.R.; Yang, Y.J. Chemical composition of five wild edible mushrooms collected from Southwest China and their antihyperglycemic and antioxidant activity. Food Chem. Toxicol. 2012, 50, 1238-1244,https://doi.org/10.1016/j.fct.2012.01.023.

39. Hleba, L.; Kompas, M.; Hutková, J.; Rajtar, M.; Petrová, J.; Čuboň, J.; Kántor, A.; Kačániová, M. Antimicrobial activity of crude ethanolic extracts from some medicinal mushrooms. J. Microbiol. Biotech. Food Sci.2016, 5, 60-63,https://doi.org/10.15414/jmbfs.2016.5.special1.60-63.

40. Liu, K.; Wang, J.; Zhao, L.; Wang, Q. Anticancer, antioxidant and antibiotic activities of mushroom Ramaria flava. Food Chem. Toxicol. 2013, 58, 375-380,https://doi.org/10.1016/j.fct.2013.05.001.

41. Bouarab-Chibane, L.; Forquet, V.; Lantéri, P.; Clément, Y.; Léonard-Akkari, L.; Oulahal, N.; Degraeve, P.; Bordes, C. Antibacterial Properties of Polyphenols: Characterization and QSAR (Quantitative StructureActivity Relationship) Models. Front. Microbiol. 2019, 10, https://doi.org/10.3389/fmicb.2019.00829.

42. Ouerghemmi, I.; Rebey, I.B.; Rahali, F.Z.; Bourgou, S.; Pistelli, L.; Ksouri, R.; Marzouk, B.; Tounsi, M.S. Antioxidant and antimicrobial phenolic compounds from extracts of cultivated and wild-grown Tunisian Ruta chalepensis. J. Food Drug Anal. 2017, 25, 350-359,https://doi.org/10.1016/j.jfda.2016.04.001.

43. Pfeffer, C.M.; Singh, A.T.K. Apoptosis: A target for anticancer therapy. Int. J. Mol. Sci. 2018, 19, https://doi.org/10.3390/ijms19020448.

44. Kumar, S.; Bajaj, S.; Bodla, R.B. Preclinical screening methods in cancer. Indian J. Pharma. 2016, 48, 481486,https://doi.org/10.4103/0253-7613.190716.

45. Youn, M.J.; Kim, J.K.; Park, S.Y.; Kim, Y.; Kim, S.J.; Lee, J.S.; Chai, K.Y.; Kim, H.J.; Cui, M.X.; So, H.S.; Kim, K.Y.; Park, R. Chaga mushroom (Inonotus obliquus) induces G0/G1 arrest and apoptosis in human hepatoma HepG2 cells. World J. Gastroenterol. 2008, 14, 511-517,https://doi.org/10.3748/wjg.14.511.

46. Higuchi, Y. Chromosomal DNA fragmentation in apoptosis and necrosis induced by oxidative stress. Biochem. Pharmacol. 2003, 66, 1527-1535,https://doi.org/10.1016/s0006-2952(03)00508-2.

47. Xu, H.; Li, X.; Ding, W.; Zeng, X.; Kong, H.; Wang, H.; Xie, W. Deguelin induces the apoptosis of lung cancer cells through regulating a ROS driven Akt pathway. Cancer Cell Int.2015, 15, https://doi.org/10.1186/s12935-015-0166-4.

48. Warren, C.F.A., Wong-Brown, M.W.; Bowden, N.A. BCL-2 family isoforms in apoptosis and cancer. Cell Death Dis. 2019, 10, https://doi.org/10.1038/s41419-019-1407-6.

49. Blagodatski, A.; Yatsunskaya, M.; Mikhailova, V.; Tiasto, V.; Kagansky, A.; Katanaev, V.L. Medicinal mushrooms as an attractive new source of natural compounds for future cancer therapy. Oncotarget. 2018, 9, 29259-29274,https://doi.org/10.18632/oncotarget.25660. 
50. Basli, A.; Belkacem, N.; Amrani, I. Health benefits of phenolic compounds against cancers. In:Phenolic compounds.Soto-Hernández, M.; Palma-Tenango, M.; Garcia-Mateos, M.R. (eds). IntechOpen, London 2017; pp. 752,https://doi.org/10.5772/67232. 